
Prace Komisji Geografii Komunikacji PTG

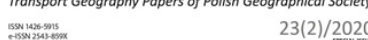

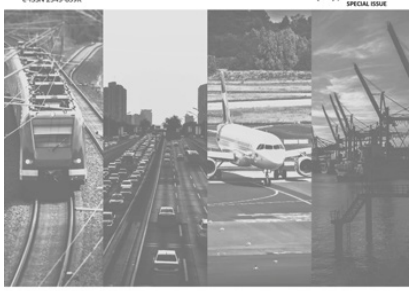

Transport Geography Papers of Polish Geographical Society

2020, 23(2), 7-13

DOI 10.4467/2543859XPKG.20.001.12099
Received: 23.05.2020

Received in revised form: 02.06 .2020

Accepted: 02.06 .2020

Published: 15.06 .2020

\title{
COVID-19 IMPACTS ON PASSENGER RAIL TRANSPORT IN HUNGARY, SLOVENIA, CROATIA, SERBIA AND ROMANIA
}

\section{Wpływ COVID-19 na pasażerski transport kolejowy na Węgrzech, w Słowenii, Chorwacji, Serbii i Rumunii}

\section{Vilmos Oszter}

KTI Institute for Transport Sciences, Than Károly u. 3-5, 1119 Budapest, Hungary

e-mail: oszter.vilmos@kti.hu

\section{Citation:}

Oszter V., 2020, COVID-19 impacts on passenger rail transport in Hungary, Slovenia, Croatia, Serbia and Romania, Prace Komisji Geografii Komunikacji PTG, 23(2), 7-13.

\begin{abstract}
The spread of the novel Coronavirus (COVID-19) has urged to take special actions to limit the level of contagion. The unprecedented scale of measures declared by the national governments in nearly every country ot the world would have a huge impact on public transport services and in general, on the citizens travel behaviours. This paper endeavours to give an overview of the emerged epidemic situation caused by COVID-19 in Hungary and some of its neighbouring Central and SouthEast European countries. It identifies the most important public transport service changes together with their interrelated impacts on the mobility patterns. The responses vary country per country so an overall comparison shows novel findings on emergency transport management policies.
\end{abstract}

Keywords: COVID-19, pandemic, Passenger transport, Rail transport, resilience 


\section{Start of the epidemic}

The general public had been informed about the start of a new epidemic from China's Hubei province by the general press starting from the second half of January with the first designate government body set up on $31^{\text {st }}$ January'. From the end of January, health check became mandatory on arriving Chinese origin flights at Budapest Airport ${ }^{2}$. The gradual withdrawal of Chinese air traffic was the only impact on the whole transport sector in the region. The situation has started to change dramatically during the first half of March 2020. On the $4^{\text {th }}$ March 2020 the first two infected patients were identified in Hungary. On the previous day, however, two tourists have been tested positive in Prague and they have spent 2 days in Budapest before on tour from Milan-Vienna-Budapest-Prague ${ }^{3}$.

On the $9^{\text {th }}$ March, Northern Italian flights have been cancelled with restricted flight offer from Chi$\mathrm{na}^{4}$. Only 2 days later on the $11^{\text {th }}$ March, a special State of Emergency was ordered by the Government of Hungary at 13 identified infected patients. The universities have been closed and only e-learning has been allowed from the $12^{\text {th }}$ March which marks the start of the sharp decrease in student traffic which normally allows over one-third of public transport PT passengers. From $16^{\text {th }}$ March all education has been done online via e-learning. The results are $95 \%$ of the drop in student traffic on PT. In Budapest and other bigger cities, the local urban transport is running on the school holidays or the weekend schedule with some adjustments.

The next major implemented restriction started in the $17^{\text {th }}$ March and since then only Hungarian residents can enter into Hungary 5 .

https://koronavirus.gov.hu/cikkek/az-operativ-torzs-akcioterve-2020-januar-31 [7.04.2020]

2 https://www.bud.hu/budapest_airport/media/hirek/ aktualis_sajtokozlemenyek/megindult_a_hatosagi_ ellenorzes_a_kinai_jaratokkal_erkezo_utasoknal.html [7.04.2020]

3 https://www.origo.hu/itthon/20200303-magyarorszagon-is-jart-ket-fertozott-diaklany-akiknel-pragaban-mutattak-ki-a-virust.html [6.04.2020]

4 https://www.bud.hu/budapest_airport/media/hirek/aktualis_sajtokozlemenyek/hetfotol_lep_eletbe_az_eszak_ olaszorszagi_jaratokkal_kapcsolatos_kormanyzati_intezkedes.html [6.04.2020]

5 https://www.bud.hu/budapest_airport/media/hirek/aktualis_sajtokozlemenyek/keddtol_a_repuloteren_sem_ lephetnek_be_magyarorszagra_a_kulfoldi_allampolgarok.html [6.04/.2020]

\section{Implemented measures in the neighbouring countries}

Due to the Slovak authorities decision from $13^{\text {th }}$ March, the GYSEV operated Rajka-Rusovce(-Bratislava) cross-border suburban connections were closed for passengers traffic, as well as the ÖBB, operated Szentgotthárd-Jennersdorf-Fehring cross-border train services were cancelled by the respective Austrian authorities decision. Some of them are replaced by buses to Jennersdorf from Szentgotthárd. Concerning the Western Hungarian - Eastern Austrian regional railway operator GYSEV/Raaberbahn the intensive cross-border traffic lines around Sopron to Wiener Neustadt/Deutschkreutz/Ebenfurth(-Vienna) are operating with the weekend schedule with some additional pair of trains in peak-hours since $23^{\text {rd }}$ March in consonance with ÖBB schedule ${ }^{6}$. FertőszentmiklósPamhagen trains are also running on a similar schedule till $9^{\text {th }}$ April when this single-track cross-border section will be closed due to planned complete reconstruction till $2^{\text {nd }}$ June. Replacement buses will be offered.

Similarly to the Slovak policy yet even stricter from the $16^{\text {th }}$ March all kind of urban and domestic public transport is stopped in Slovenia including the Budapest-Ljubljana trains which were initially cut back till the town of Öriszentpéter close to the SlovenianHungarian border?

The train cancellations were instantly implemented towards Croatia as from $15^{\text {th }}$ March the BudapestGyékényes-Zagreb direct train pair and from $17^{\text {th }}$ March the regional cross-border services between Magyarbóly and Beli Manastir have been cut back. Following the example of Slovenia, after having cut all cross-border connection on the $17^{\text {th }}$ March all kind of urban and domestic public transport was stopped in Croatia for 30 days starting from $22^{\text {nd }}$ March $^{8}$.

Looking towards the other ex-Yugoslavian Southern neighbour of Hungary the Serbian Railways has also stopped gradually international trains between $16^{\text {th }}$ and $20^{\text {th }}$ March and introduced a limited schedule for domestic services 9 .

6 https://www2.gysev.hu/belfoldi-utazasok/vaganyzarakkozlekedesi-informaciok [10.04.2020]

7 https://www.slo-zeleznice.si/en/passenger-transport/ timetable/passenger-transport-canceled [9.04.2020]

8 www.hzpp.hr\%2Fprivremeno-obustavljen-zeljeznicki-pri jevoz\%3Ffbclid\%3DIwAR0zbxKWD8QTMGXagZqENzrKaf XvNXQhA-1 Auu9k2RhP5CWZVaqzTatRZMs\&h=AT2_qcss KCo9nerTU_6YI9n4nA5RrUrW5k3GvoH494sucZx4buEMP ehsSW-svviVVQzEEgK12z9NxMgN6-OFJQvCylbjeX1yZm aumDN30vsAtbgp8Hodd6m1_5AaTGz_2w [7.04.2020]

9 https://www.srbvoz.rs/izmena-reda-voznje-za-unutrasnji-saobracaj-vozova/ [8.04.2020] 
From $20^{\text {th }}$ March the last remaining daily KelebiaSubotica(-Novi Sad) cross-border train pair to Serbia from Hungary has been cancelled. Only the connecting domestic service remains to Budapest via Kiskunhalas and Fülöpszállás. Concerning Serbia's key domestic passenger rail operation Belgrade's (sub) urban "S-Bahn" Beovoz has also implemented a restricted schedule with last trains before 8 p.m. since $20^{\text {th }}$ March. Touristic narrow gauge service in Mokra Gora is also cancelled until further notice.

Heading eastern direction very similar paralysation took place from the $17^{\text {th }}$ March when Romanian international connections have been cut except for Biharkeresztes-Episcopia Bihor border crossing which was cancelled on the $18^{\text {th }}$ March. Romanian longdistance and some badly-hit quarantine areas around the South-East part of Romania seen domestic cuts, more details of which can be found in details on the next link as of $6^{\text {th }}$ April. International trains have been cancelled fully on 18-19 $9^{\text {th }}$ March $^{10}$.

All of the Romanian private passenger operators have also introduced several cuts from the $24^{\text {th }}$ March when the movement restrictions (ORDONANȚEI MILITARE nr. 3 din 24.03.2020) entered into force and should last at least till $14^{\text {th }}$ April. Most of them are complete cancellations on competition routes with some Sunday services remained (https://www.astratranscarpatic.ro/\# and https://www.transferoviarcalatori.ro/). Certain secondary lines with an already low number of connections have been temporarily cancelled. There is no information about the informal minibus replacement services which are likely to get shut down too.

Similarly to the example of the Slovenian and Croatian authorities on the $17^{\text {th }}$ March all cross-border trains has been cancelled between Záhony and Chop in Ukraine. Ukraine has also stopped all public transport from $18^{\text {th }}$ March initially for 14 days.

Since then only Hegyeshalom border crossing (towards Vienna, Austria) has had restricted passenger service operation with 2 daily pairs of Eurocity trains to Vienna for further connections. One night Euronight train with direct carriages only to Munich (EN Kálmán Imre) the Zürich part is cancelled. Sleeping cars, couchettes and restaurant cars are cancelled. Furthermore, 2 daily pair of Railjet operates where takeaway only catering is possible. Euroregio trains are running from Győr till to Bruck and der Leitha only from where connecting ÖBB trains run to Vienna with the weekend schedule.

\footnotetext{
10 https://www.cfrcalatori.ro/comunicate/masuri-circulatie-trenuri-pentru-asigurarea-protectiei-calatorilor-peperioada-starii-de-urgenta/\# [8.04.2020]
}

\section{Implemented measures in Hungary}

Following the average $85 \%$ drop in paying passenger numbers ( $77 \%$ for active full price commuters) the Ministry for Innovation and Technology ordered to cut fully or mostly domestic sections of the already cut international trains instead of the border stations. The changes went together with the domestic traffic school holiday timetable in operation on both MÁV-START and GYSEV lines since $30^{\text {th }}$ March. The train capacity has been adjusted according to the especially changed travel demand yet physical distancing between passengers became the new norm. An overall decrease in the offered capacity is observable, particularly the older rolling stock has been stopped where possible yet not exact numbers are available. From the ca. 3300 daily passenger train services of the incumbent operator MÁV-START in total 150 trains were cancelled according to the CEO announcement ${ }^{11}$. The ca. $4.54 \%$ decrease in the number of trains is similar to the regional passenger rail operator's decrease rate. Overall in Hungary, there are no any regular PSO passenger service railway lines out of traffic only some busy main lines saw cuts in peak-hours and marginal departures reduction. This applies to the bus PSO transport network whose feeder function has been promoted in the media yet no exact information is available for the moment. Due to the significantly (ca. $-85 \%$ ) decrease occupancy rate and to prevent contagion it is now officially allowed to seat further away instead of the assigned seat in case of trains with mandatory seat reservations. At the same time from $27^{\text {th }}$ March free travel on any domestic public transport mean is provided for all healthcare workers even on mandatory supplement IC trains where they can take the free seats.

The most important domestic section cuts of the former international trains are the followings ${ }^{12}$ :

Towards Austria, most Railjets were cancelled in the domestic section (Budapest-Györ-Hegyeshalom) as well as certain transit (Vienna-Transylvania) Euro City trains on this line including the Szamos-Transilvania EC (Vienna-Budapest-Satu Mare/Cluj). As a result of weak travel demand in the sparsely populated Örség micro-region near the Hungarian-Slovenian border, the Citadella fast train Budapest-Ljubljana has been cut back from the small town of Öriszentpéter to the county capital city of Zalaegerszeg only.

11 https://www.origo.hu/itthon/20200407-mav-80-szazalekkal-esett-vissza-az-utasszam-az-elozo-evhez-kepest. html [7.04.2020]

12 https://www.mavcsoport.hu/sites/default/files/upload/ page/covid_19_valtozasok_v0402.pdf [7.04.2020] 


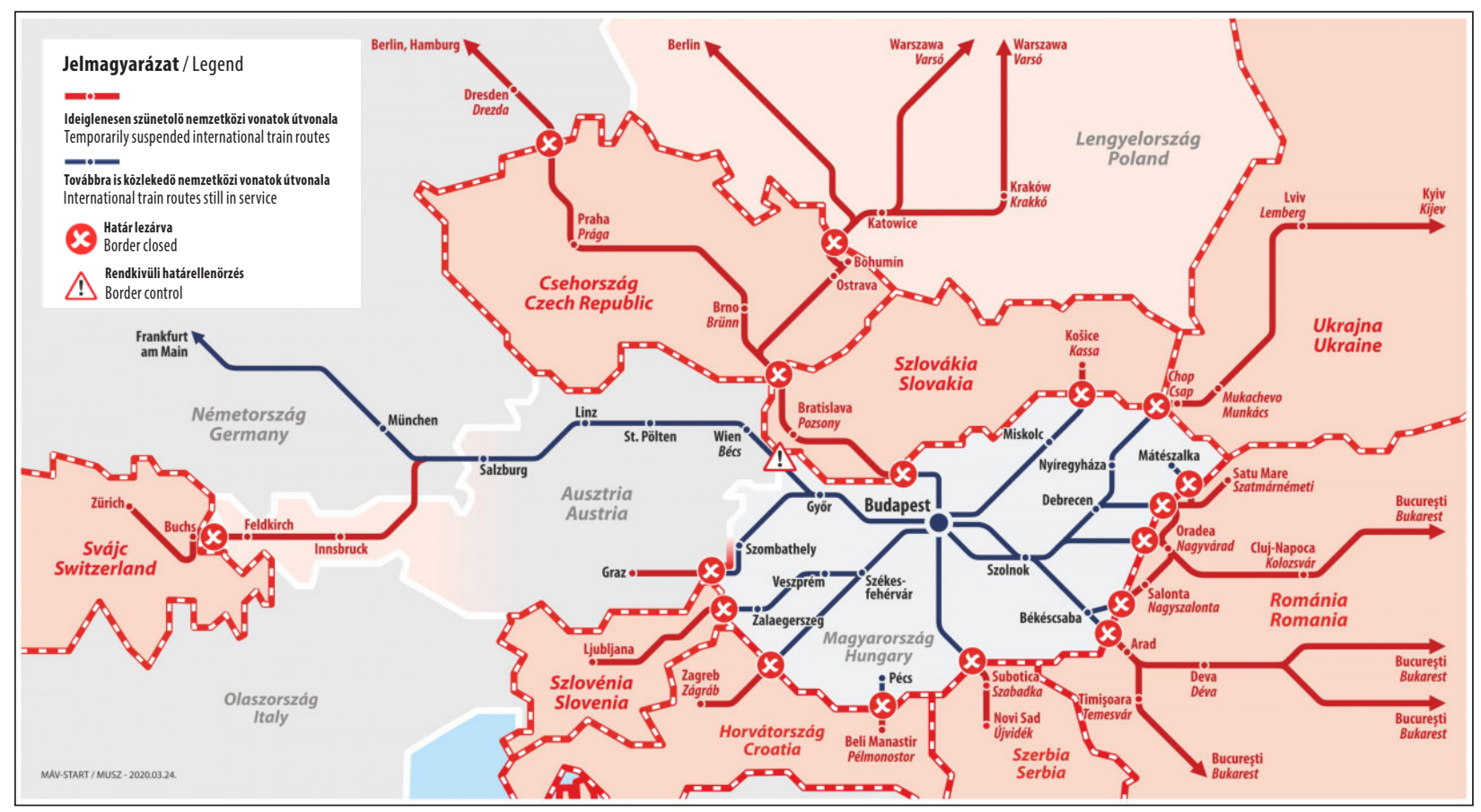

Fig. 1. Passenger train service cuts in Central Europe as of early April 2020.

Source: https://www.mavcsoport.hu/sites/default/files/upload/story/document/public/trkp_hvr_eur_valtozasok_a3_071_2020-03-24.pdf [7.04.2020]

The express trains "Sugovica" on the Budapest-Szekszárd-Baja line which circulate on Friday and Sunday only and are normally formed from single Desiro DMU have been cancelled together with some student traffic-related peak hours commuter trains across the network. A similar purpose Friday-Sunday Szeged-Miskolc student trains ("Campus Express") bypassing Budapest via Jászberény have been also cancelled together with some additional special tariff "televonat" services which are normally competing with rider-sharing application services for the weekly commuters on Sunday afternoons from Szeged-Kecskemét and NyíregyházaDebrecen direction to the capital city Budapest.

Due to the very weak travel demand and to the scheduled optimised for the already withdrawn international connections from $30^{\text {th }}$ March Metropol EC and other international services (to Bratislava/ Prague/Berlin/Poland) via Szob-Stúrovo were cancelled fully for the Hungarian domestic section as well as the Budapest-Košice 2 daily direct trains runs only till to county capital city of Miskolc instead of the small border village of Hidasnémeti.

On the contrary, all the way standard gauge Transcarpathia connection to Ukraine's westernmost major city with standard (dual) gauge station $\mathrm{Mu}$ kachevo, named after nearby river Latorca IC runs only between Budapest and Záhony as the domestic role of this service is significantly higher than the Slovak bound services mentioned above. Similarly, some peak-hour services and the traditional less crowded first/last IC pair between Budapest and Nyíregyháza/Záhony are cancelled. Concerning Eastern Hungary, other minor regional international trains are cancelled or are running as local trains serving local passengers between Püspökladány and Biharkeresztes also between Debrecen and Nyírábrány on the Romanian-Hungarian border.

As an interesting example, Dacia fast train (a former night train) runs only between Budapest (instead of Bucharest) and Vienna on its diurnal section only. Other international trains towards its route run till Lőkösháza border station. The nearby Békéscsaba-Salonta regional trains are running only till Kötegyán border station.

Some Szeged and Újszeged-Békéscsaba connections are cancelled fully or partly as they were regional weekly student commuter services but other services remain in service. It should be mentioned that on the westernmost section between Szeged and Hódmezővásárhely there is an ongoing closure due to track reconstruction for the new tram-train.

Finally, as a measure to keep citizens home and practice social distancing to slow the spread of the epidemic all touristic narrow gauge railway services in Hungary are stopped since $17^{\text {th }}$ March except for the PSO services of Balatonfenyves and Somogyszentpál. In all cases the joining touristic attractions, accommodations, thermal spas as well due to the declared state of the emergency. 


\section{Restart of services}

In Hungary following the peak in the registered infected persons from 3 May $2020^{13}$ the travel restrictions have been gradually released first in the countryside with 2 weeks ahead of Budapest and Central Hungary. Consequently, leisure trains were gradually put into service between $09^{\text {th }}$ May and early June ${ }^{14}$. On the other hand special "so-called" pandemic restricted passenger trains service timetable ${ }^{15}$ entered into force on $6^{\text {th }}$ June on numerous regional railway lines leaving only 1 or 2 daily train services on most of the indicated lines of Figure 2. The red coloured line shows that additional replacement buses are employed to replace the withdrawn trains. On the blue marked lines existing parallel bus services runs until further notice. hand, regional cross-border services only between Austria and Hungary were running again as the original timetable from the $11^{\text {th }}$ May but long-distance international connections have become becoming gradually more frequent by the end of June. In all other border crossings from Hungary with the exception of Ukraine, the regional and long-distance crossborder services are restarting from the beginning of July. ${ }^{17}$ Apart from the lack or reduced restaurant cars and the cancellation of two direct Budapest-Adriatic seaside seasonal overnight services the rest of the services will run again as it was originally scheduled. Nearly two months after the weakest travel demand at the end of April the passengers gradually returns to the rail services as by June all the domestic travel restrictions were released by June followed by the termination of the state of emergency on the $17^{\text {th }}$

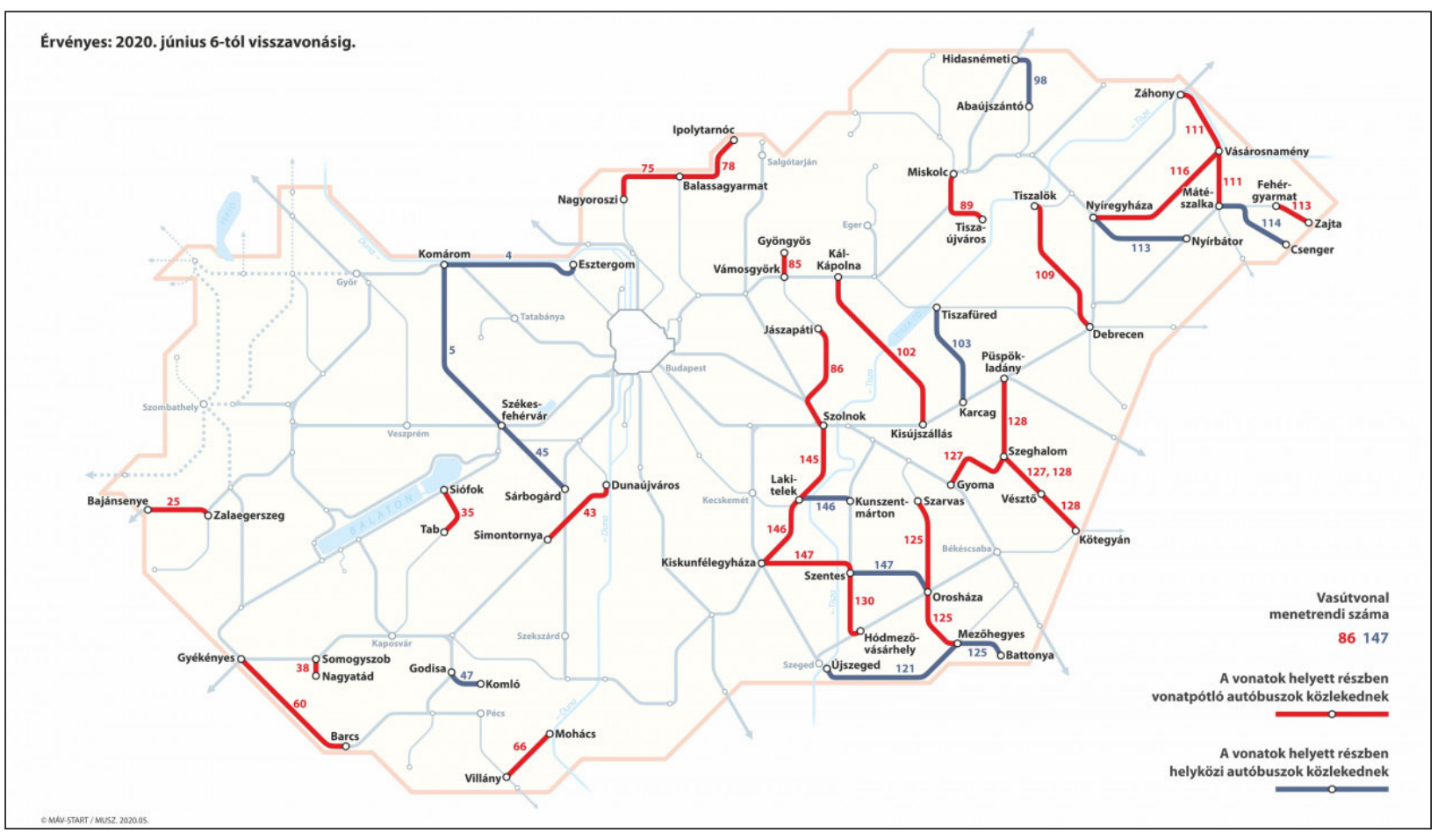

Fig. 2. Passenger train service cuts in Hungary as of early June 2020

Source: https://www.mavcsoport.hu/mav-start/ideiglenes-jarvanyugyi-menetrendek-regionalis-vasutvonalakon (23/04/2020)

Most of the surrounding countries resumed their domestic passenger train services from the middle of May with some limited services as well ${ }^{16}$. On the other

13 https://koronavirus.gov.hu/cikkek/fokozatosan-csokken-az-aktiv-fertozottek-es-korhazban-apoltak-szama-0 [3.04.2020]

14 https://kisvasut.hu/view_cikk.php?id=3702 [23.04.2020]

15 https://www.mavcsoport.hu/mav-start/ideiglenes-jarvanyugyi-menetrendek-regionalis-vasutvonalakon [23.04.2020]

16 http://www.hzpp.hr/en/railway-traffic-in-croatia?p=75 [23.04.2020]
June ${ }^{18}$. Somehow surprisingly a new open-access private operator entered into the international rail passenger market for the first time in Croatia, Hungary and Slovenia as the Czech private operator Regiojet initially start 3 times weekly (increased to daily in peak period) seasonal overnight trains with

17 https://www.mavcsoport.hu/mav-csoport/restart-juliustol-szamos-nemzetkozi-vonat-ujraindul [23.04.2020]

18 http://abouthungary.hu/news-in-brief/coronavirusheres-the-latest/ [23.04.2020] 
feeder buses to the Croatian port city of Rijeka ${ }^{19}$. During the summer season, this will be the only direct overnight seaside service from Hungary by using the Western Hungarian regional railway GYSEV station at Csorna.

The key international (V4) "Metropol" corridor is still operating only between Czechia and Slovakia as the Hungarian connecting section will remain closed until the landslide damaged infrastructure reopens near the Slovak-Hungarian border at Dömös by midJuly.

\section{Discussion and Conclusion}

To conclude one might observe that the response given by decreasing the public transport services largely depends on the given country's epidemic protection policy. One extreme is lead by Ukraine, Slovenia and Croatia where $100 \%$ of public transport was shut down at the start of the epidemic. Countries like Romania, Serbia or even Slovakia have significantly reduced passenger service offer and in some suburban cases operating hours. At all the countries firstly the international and non-essential services have been cut too as well as all touristic services. Hungary with ca. $4.54 \%$ reduction of the domestic railway timetable offer can be considered as the other end. Still, due to the other countries decisions, the border-crossing and service restrictions made $97 \%$ of the cross-border passengers disappear for the main rail operator MÁV-START. As the first available official results show for the first quarter (Q1) of 2020 passenger rail traffic was a bit less impacted by the first wave of the pandemic as it decreased $6 \%$ versus the $17 \%$ of the regular domestic bus services ${ }^{20}$. It is important to note here that only the last month of Q1 (March) was impacted by the pandemic, therefore the coming quarters will give a better picture about the real change of travel demand and modal shifts. It is worth to mention that the historically high modal split of public transport and the $99.9 \%$ of network coverage for Hungary's 3155 independent settlements (LAU2) still makes for certain elderly people and some lowincome commuters the only way of the mobility. Unfortunately, this group seems to be the main target group for the current COVID-19 epidemic and their travel needs were asked to be reduced. People above 65 years were allowed by special law to go to shops, groceries, pharmacies etc between 9 and 12 a.m. (until mid-June). As a prevention measure by early May,

\footnotetext{
19 https://www.regiojet.com/croatia/index.html [25.04.2020]

20 http://www.ksh.hu/docs/hun/xftp/stattukor/sza/20201/ index.html [23.04.2020]
}

all the public transport operators made mandatory the wearing of masks on board of trains and other public transport means while travelling.

Based on Google's locational data the changes from the January-February bases compared with the $29^{\text {th }}$ March concerning access to transit stations (all kind of public transport stops not just railways) are also the smallest in Hungary yet in Budapest with many home office ready jobs is different than the rest of the country.

Tab. 1. Decrease in public transport usage in January-February 2020 compared to normal levels in selected countries and their capitals, measured by Google according to smartphone locational data at public transport stops

\begin{tabular}{|l|r|l|r|}
\hline Country & \multicolumn{3}{|c|}{ Capital city } \\
\hline Hungary & $53 \%$ & Budapest & $67 \%$ \\
\hline Slovakia & $61 \%$ & Bratislava & $64 \%$ \\
\hline Croatia & $74 \%$ & Zagreb & $76 \%$ \\
\hline Slovenia & $54 \%$ & Ljubljana & $58 \%$ \\
\hline Romania & $72 \%$ & Bucharest & $74 \%$ \\
\hline
\end{tabular}

* Slovenian data in earlier days of $29 / 03$ is closer to the $80 \%$ decrease yet still higher than expected after having cancelled all public transportation $\mathrm{n}$ the entire county. Ukraine and Serbia are not on the list.

Source: https://www.google.com/covid19/mobility/ [data till 29.03.2020]

\section{Literature}

http://abouthungary.hu/news-in-brief/coronavirus-heresthe-latest/ [23.04.2020]

http://www.hzpp.hr/en/railway-traffic-in-croatia?p=75 [23.04.2020]

http://www.ksh.hu/docs/hun/xftp/stattukor/sza/20201/ index.html [23.04.2020]

https://kisvasut.hu/view_cikk.php?id=3702 [23.04.2020]

https://koronavirus.gov.hu/cikkek/az-operativ-torzs-akcioterve-2020-januar-31 [7.04.2020]

https://koronavirus.gov.hu/cikkek/fokozatosan-csokkenaz-aktiv-fertozottek-es-korhazban-apoltak-szama-0 [23.04.2020]

https://www.astratranscarpatic.ro/\# [8.04.2020]

https://www.bud.hu/budapest_airport/media/hirek/ aktualis_sajtokozlemenyek/megindult_a_hatosagi_ ellenorzes_a_kinai_jaratokkal_erkezo_utasoknal.html [7.04.2020]

https://www.bud.hu/budapest_airport/media/hirek/ aktualis_sajtokozlemenyek/hetfotol_lep_eletbe_az_ eszak_olaszorszagi_jaratokkal_kapcsolatos_kormanyzati_intezkedes.html [6.04.2020] 
https://www.bud.hu/budapest_airport/media/hirek/ aktualis_sajtokozlemenyek/keddtol_a_repuloteren_ sem_lephetnek_be_magyarorszagra_a_kulfoldi_allampolgarok.html [6.04.2020]

https://www.cfrcalatori.ro/comunicate/masuri-circulatietrenuri-pentru-asigurarea-protectiei-calatorilor-peperioada-starii-de-urgenta/\# [8.04.2020]

https://www.google.com/covid19/mobility/ [5.04.2020]

https://www.mavcsoport.hu/mav-csoport/restart-juliustol-szamos-nemzetkozi-vonat-ujraindul [23.04.2020]

https://www.mavcsoport.hu/mav-start/ideiglenesjarvanyugyi-menetrendek-regionalis-vasutvonalakon [23.04.2020]

https://www.mavcsoport.hu/sites/default/files/upload/ page/covid_19_valtozasok_v0402.pdf [7.04.2020]

https://www.mavcsoport.hu/sites/default/files/upload/ page/mnr_nemzetkozi-2020_teljes_koronavirus_idejen.pdf [7.04.2020]

https://www.mavcsoport.hu/sites/default/files/upload/ story/document/public/trkp_hvr_eur_valtozasok_ a3_07-1_2020-03-24.pdf [7.04.2020] https://www.origo.hu/itthon/20200303-magyarorszagonis-jart-ket-fertozott-diaklany-akiknel-pragaban-mutattak-ki-a-virust.html [6.04.2020]

https://www.origo.hu/itthon/20200407-mav-80-szazalekkal-esett-vissza-az-utasszam-az-elozo-evhez-kepest. html [7.04.2020]

https://www.regiojet.com/croatia/index.html [25.04.2020] https://www.slo-zeleznice.si/en/passenger-transport/ timetable/passenger-transport-canceled [9.04.2020] https://www.srbvoz.rs/izmena-reda-voznje-za-unutrasnjisaobracaj-vozova/ [8.04.2020]

https://www.transferoviarcalatori.ro/ [8.04.2020]

https://www2.gysev.hu/belfoldi-utazasok/vaganyzarakkozlekedesi-informaciok [23.04.2020]

www.hzpp.hr\%2Fprivremeno-obustavljen-zeljeznicki-prij evoz\%3Ffbclid\%3DIwAR0zbxKWD8QTMGXagZqENzrK afXvNXQhA-1Auu9k2RhP5CWZVaqzTatRZMs\&h=AT2 qcssKCo9nerTU_6YI9n4nA5RrUrW5k3GvoH494sucZx 4buEMPehsSW-svviVVQzEEgK12z9NxMgN6-OFJQvCyIbjeX1yZmaumDN30vsAtbgp8Hodd6m1_5AaTGz_2w [7.04.2020] 